\title{
IN SEARCH OF FINAL BREAKDOWN IN WATER-TREE DEGRADED XLPE
}

\author{
Non-members S. Pélissou N. Amyot (HYDro-QuÉBEC) \\ Non-member B. Noirhomme (SYPROTEC)
}

\begin{abstract}
With an objective to study the final dielectric breakdown process by which a water tree converts into an electrical tree, characterized (density, impurity and water content, water tree density, oxidation) crosslinked polyethylene (XLPE) samples taken from two $28 \mathrm{kV}$ field-aged cables were aged at $10 \mathrm{kV} / \mathrm{mm}, 60 \mathrm{~Hz}$ electric stress in the presence of 0.05 or $1 \mathrm{M} \mathrm{NaCl}$ electrolyte at $22-23^{\circ} \mathrm{C}$. The results indicate that water tree growth saturated as a function of test time and was only slightly influenced by $\mathrm{NaCl}$ concentration. Also it was found that the length of laboratory grown water trees was not affected by the presence of field grown water trees. The AC breakdown (ACBD) strength was influenced to a certain extent by the length of laboratory grown water trees. The aging conditions have led to the growth of non-conductive water trees which have almost no electric field enhancement at their tips and subsequently with no possibility to generate pre-breakdowns or electrical trees. Other mechanisms such as surge or lightning impulses, or partial discharges at operating voltage must be considered in order to effect the conversion of water trees to electrical trees.
\end{abstract}

Key words: Water trees, electrical tree inception, final breakdown mechanism, laboratory-aged field-aged XLPE.

\section{INTRODUCTION}

Crosslinked polyethylene (XLPE) insulated cables, when exposed to the combined effect of electric stress and water, are susceptible to a form of degradation known as water treeing [13]. This type of defect causes a significant reduction in the breakdown strength of the cable insulation and is regarded as the major cause of premature cable failure [4]. Three stages can be considered in the degradation due to water trees: initiation, growth and final breakdown. The first two stages have been studied extensively (see for example [5] and [6]), but their mechanisms are still not well understood. However, less attention has been paid to the final breakdown process by which a water tree converts into an electrical tree and eventually results in the puncture of the insulation. There are several evidences in the literature [5-11] for such a phenomenon. However, there is still a lack of consensus as to how this conversion takes place.

This paper presents the results of a study performed to determine the final breakdown mechanism [12-14], by studying the initiation phase of electrical trees in moisture-degraded cable insulation. It essentially concerns laboratory aging, a measurement of $\mathrm{AC}$ breakdown (ACBD) strength and an examination of samples taken from the insulation of field-aged distribution cables. Two cables with distinct insulation characteristics (water content, impurity contamination, water tree density and ACBD strength) were chosen in order to study their influence on the final breakdown mechanism.

\section{2 . EXPERIMENTAL}

The tests were performed on $600 \mu \mathrm{m}$ thick ribbons peeled off [15] from two field-aged $28 \mathrm{kV}$ cables, namely $\mathrm{HQ} 3$ and HQ4, having different insulation characteristics. These cables were XLPE-insulated and steam-cured. They failed in service after 6 and 12 years respectively. The characteristics of their insulation are given in Table 1 where it is shown that cable HQ3 has higher insulation density, contains more impurities and more field-grown water trees [16, 17] than cable HQ4. All field-grown water trees are of bow-tie type since the samples are taken from the bulk of the cable insulation. The designations heavily and weakly in Table 1 come from a comparison made between eight field-aged cables, HQ3 being the most contaminated and HQ4 the least. On the other hand, HQ4 insulation has higher water content with lower dielectric strength. The insulation of both cables has roughly the same level of oxidation. 
Table 1. Cable insulation characteristics

\begin{tabular}{|l|c|c|}
\cline { 2 - 3 } \multicolumn{1}{c|}{} & $\mathrm{HQ3}$ & $\mathrm{HQ} 4$ \\
\hline Density $\left(\mathrm{g} / \mathrm{cm}^{3}\right)$ & 0.9180 & 0.9146 \\
\hline Impurity contamination $(1)$ & heavily & weakly \\
\hline Water tree density $\left(\mu \mathrm{m} / \mathrm{mm}^{3}\right)(2)$ & 68.8 & 57.0 \\
\hline Mean water content $(\mathrm{ppm})$ & 452 & 1530 \\
\hline Mean ACBD strength $(\mathrm{kV} / \mathrm{mm})(3)$ & 14.4 & 8.9 \\
\hline Mean oxidation level $(\mathrm{mol} / \mathrm{L})(4)$ & $2.5 \times 10^{-3}$ & $1.9 \times 10^{-3}$ \\
\hline
\end{tabular}

(1) Impurities as measured by neutron activation analysis: $\mathrm{Na}, \mathrm{K}, \mathrm{Ca}, \mathrm{Cl}, \mathrm{Al}, \mathrm{Cu}, \mathrm{S}$.

(2) Mean water tree density weighted with their mean length

(3) performed on six cable samples in conformity with the AEIC CS5-87 specification.

(4) Bouguer-Beer's law was used for the calculations with an extinction coefficient of $320 \mathrm{~L} / \mathrm{mol} . \mathrm{cm}$

The ribbons were sand-blasted on one side, cut in pieces of $2.5 \mathrm{~cm}$ diameter, and a $1.5 \mathrm{~cm}$ diameter gold disk was evaporated on the opposite side. Several cells such as the one shown in Figure 1 were used for laboratory aging [18]. In the cells either a 0.05 or $1 \mathrm{M} \mathrm{NaCl}$ solution was applied to the sand-blasted side of the specimens. The tests were performed at $10 \mathrm{kV} / \mathrm{mm}, 60 \mathrm{~Hz}$ frequency and at room temperature. After being subjected to various periods of aging, the specimens were removed and either directly subjected to an ACBD test and/or analyzed for treeing. The ACBD tests were performed with a Baur high voltage source using a microprobe cell $(3 \mathrm{~mm}$ diameter stainless steel cylinders as electrodes) immersed in silicone oil, and at a constant voltage increase of $0.5 \mathrm{kV} / \mathrm{s}$. The water trees were examined, for each specimen, on two pairs of $400 \mu \mathrm{m}$ thick slices cut perpendicularly to each disk sample. The two pairs were selected arbitrarly $90^{\circ}$ apart and stained with a methylene blue solution in accordance with general practice. The analysis consisted mainly of recording the length and shape of water trees under an optical microscope.

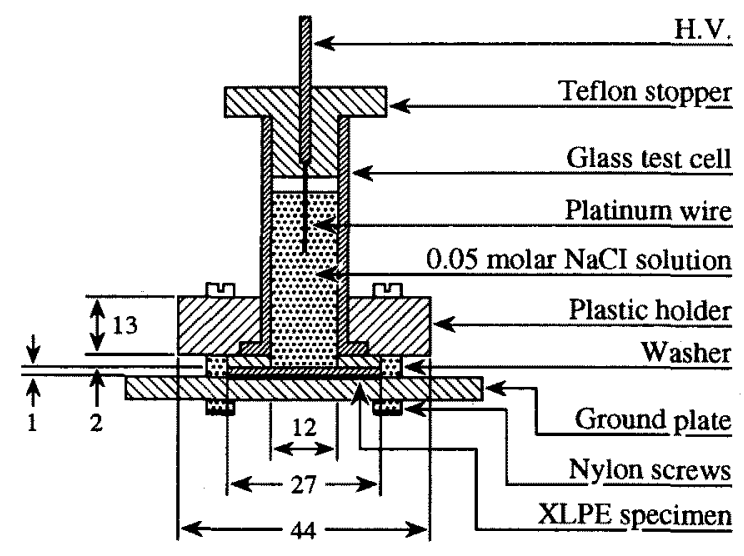

Fig. 1. Accelerated aging cell from Bulinski et al. [18]
In order to obtain a local electric field enhancement, a needle (curvature radius $=6 \mu \mathrm{m}$ ) was used to pit the sandblasted surface of some samples at five different places (die arrangement), down to a depth of $150 \mu \mathrm{m}$ ( $25 \%$ of the sample thickness). The contact between the electrolyte ( $1 \mathrm{M} \mathrm{NaCl})$ and the polymer at these pits was improved by outgassing in a vacuum chamber at roughing pressure.

\section{RESULTS AND DISCUSSION}

The length of laboratory grown water trees expressed as a percentage of insulation thickness are represented in Figures 2 and 3 for cables HQ3 and HQ4 respectively, the data points stand for different samples taken from various insulation ribbons and representing the entire insulation thickness. The laboratory-aged water trees essentially consist in vented trees. Although data points are quite scattered it can be estimated that on an average the water tree growth rate in either cable samples decreased with aging time, and the tree length saturated at around $70 \%$ of the sample thickness over 8000 hours of aging with $0.05 \mathrm{M}$ solution. With the $1 \mathrm{M}$ solution, the saturation was not reached due to the reduced aging period: 5000 hours. The general trend of the water tree propagation curves is in relative agreement with those of other researchers [18-20], i.e rapid increase at the beginning and saturation to a greater or lesser extent afterwards.

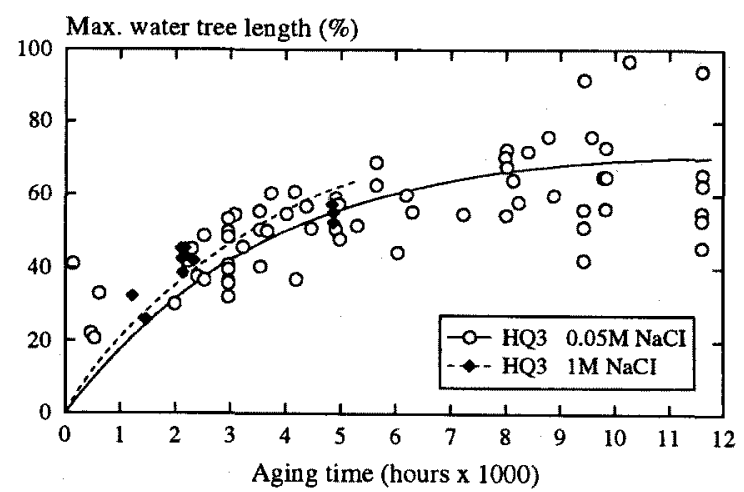

Fig. 2. Maximum lab-water tree length of $\mathrm{HQ}^{3}$ samples as a function of aging time (conditions: $60 \mathrm{~Hz}, 10 \mathrm{kV} / \mathrm{mm}, 22-$ $23^{\circ} \mathrm{C}$ ) for two $\mathrm{NaCl}$ solution concentrations. Expressed as a percentage of sample thickness.

However, differences appear when comparing tree length values, particularly with the results obtained by Bulinski et al. [18] on unaged cable samples using the same aging conditions (sample thickness $0.6 \mathrm{~mm}$, same aging cell, room temperature, $0.05 \mathrm{M} \mathrm{NaCl}$ solution), but with half the electrical stress (5 $\mathrm{kV} / \mathrm{mm}$ ). They found water tree lengths of $50 \%$ and $70 \%$ of 
sample thickness after respectively 1000 and 3000 hours, while our results lead to only $20 \%$ and $40 \%$. These differences could be explained by the fact that our samples, taken from field-aged cables, are more oxidized, and hence more watertree resistant, as concluded by these authors [18]. Using an electrical field twice as high was not sufficient to obtain longer water trees for the same aging time.

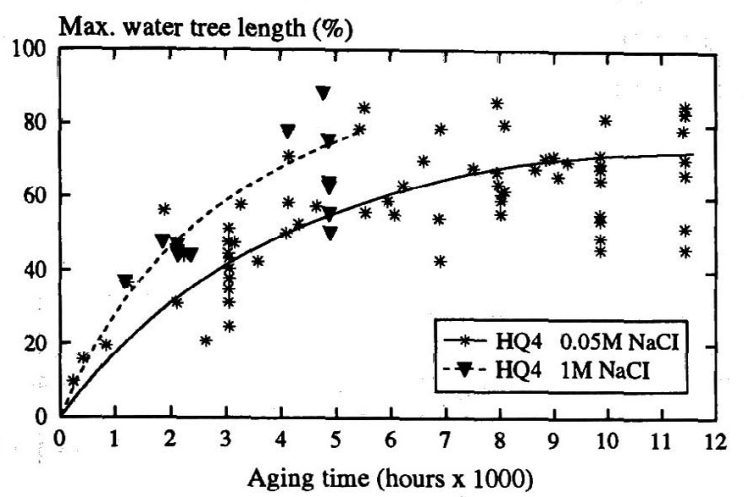

Fig. 3. Maximum lab-water tree length of HQ4 samples as a function of aging time (conditions: $60 \mathrm{~Hz}, 10 \mathrm{kV} / \mathrm{mm}, 22$ $23^{\circ} \mathrm{C}$ ) for two $\mathrm{NaCl}$ solution concentrations. Expressed as a percentage of sample thickness.

Other observations are: (1) more pronounced effect of ion concentration in HQ4 than in HQ3 which may be due to its higher microvoid density and/or size, or to its lower density (Table 1), water tree growth could have been facilitated by either of these material parameters; (2) no correlation was found between the position with reference to the insulation thickness and water tree length as depicted for $\mathrm{HQ}_{3}$ samples in Figure 4, tests on cable HQ4 have led to similar results. The scatter in the data expressed by this method of analysis may be explained by the varying distribution of impurities and microcavities within the insulation of a cable $[21,22]$.

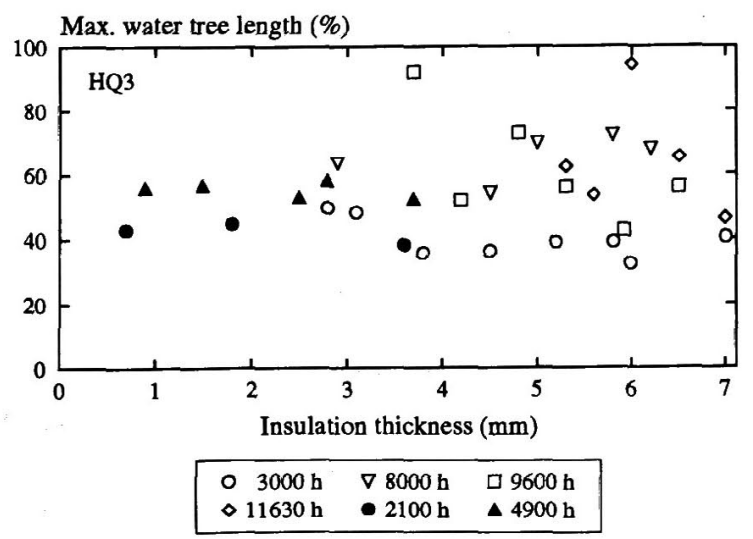

Fig. 4 - Maximum water tree length, expressed in percent of sample thickness, as a function of the sample position in the insulation thickness.
Figure 5 shows the microscopic features of the laboratorygrown water trees for both cable samples. They appear more dense than the field-grown water trees and have a higher microcavity density in comparison with the untreed insulation. These observations confirm the increase of water content of the water treed region with aging time as noted by Bulinski et al. [18]. The uniformity in water tree length (Figure 5.a) or its spread (Figure 5.b, c, d) did not bear any particular trend with regards to the type of the cable or aging time. Such variations could be attributed to differences in roughness of the sandblasted surfaces.

a)

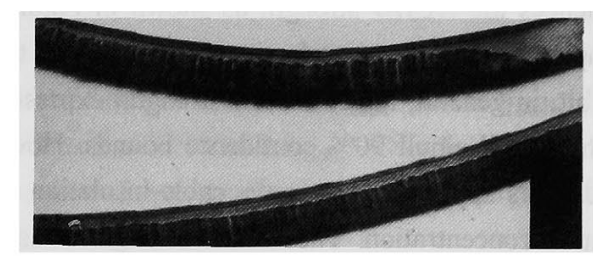

b)

$\mathrm{x} 62.5$

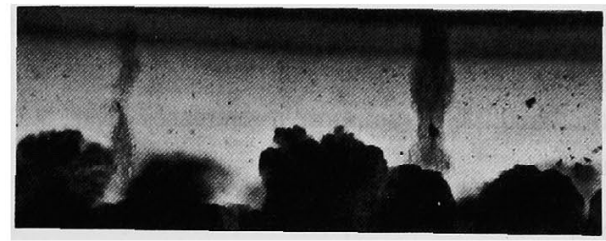

c)

62.5

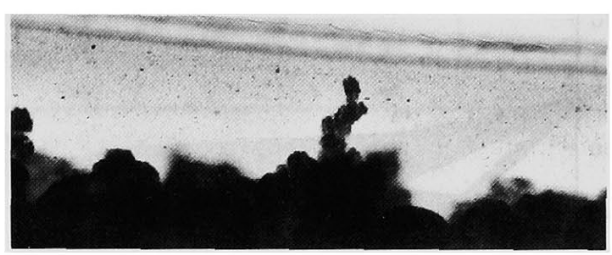

d)

$x 62.5$

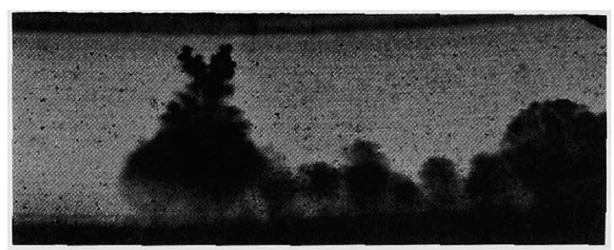

Fig. 5. Shape of the lab-water-trees:
a) $\mathrm{HQ} 3-0.05 \mathrm{M} \mathrm{NaCl}-10275$ hours $-1_{\max }=97 \%$
b) $\mathrm{HQ} 4-0.05 \mathrm{M} \mathrm{NaCl}-9069$ hours $-1_{\max }=65 \%$
c) $\mathrm{HQ} 4-1 \mathrm{M} \mathrm{NaCl}-4815$ hours $-\mathrm{I}_{\max }=88 \%$
d) $\mathrm{HQ} 4-0.05 \mathrm{NaCl}-11454$ hours $-1_{\max }=84 \%$
$1_{\max }$ : maximum lab-water-tree length

Furthermore, the presence of field-grown bow-tie trees in the test samples did not influence the subsequent tree growth pattern of the laboratory-grown water trees (Figure 5.b). In some cases bow-tie trees were even found to bridge the sample's thickness without affecting the laboratory-tree growth. If bow-tie trees were conductive, as often admitted $[4,5]$, one would have expected a greater laboratory water tree 
growth near their tips due to electrical stress enhancement. Since this is not the case, we ought to consider that water trees grown with a $0.05 \mathrm{M}$ or $1 \mathrm{M} \mathrm{NaCl}$ solution are not giving rise to high enough electric field enhancement at their boundaries and that they more or less behave as a dielectric, as already suggested by Koo and Koo et al. [23,24]. In this way, the higher field-grown water tree density of cable HQ3 (Table 1) did not help to obtain longer laboratory-aged water trees in comparison with cable HQ4.

Nevertheless, the presence of laboratory-grown water-trees influences the ACBD strength as shown in Figures 6 and 7 . Samples aged longer, or having greater water tree lengths, exhibit, in general, lower ACBD strength, expressed in terms , of the two Weibull $90 \%$ confidence bounds. However, some differences appear regarding the cable insulation or the $\mathrm{NaCl}$ solution concentration. The ACBD strength of samples HQ3 is not much influenced by the ion concentration (at least up to 5000 hours) or after immersion in distilled water for nearly 9 months ( 2 months immersion led to an identical result), also with the $0.05 \mathrm{M}$ solution it increases over 8000 hours of aging.

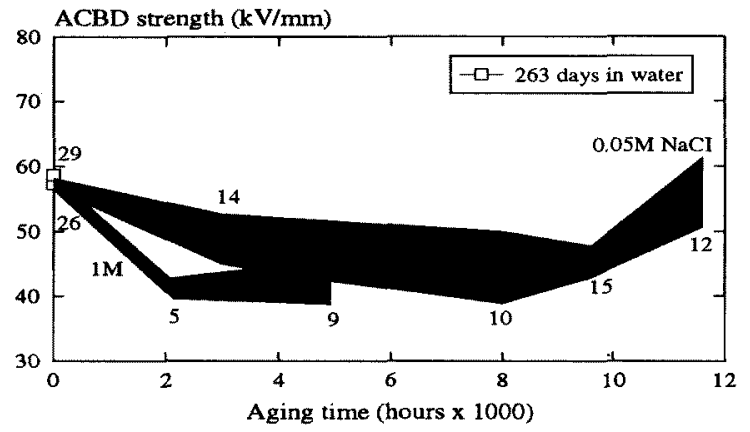

Fig. 6 - ACBD strength (Weibull $90 \%$ confidence intervals) of $\mathrm{HQ} 3$ samples as a function of aging time for two $\mathrm{NaCl}$ solution concentration. The numbers refers to the number of sample tested.

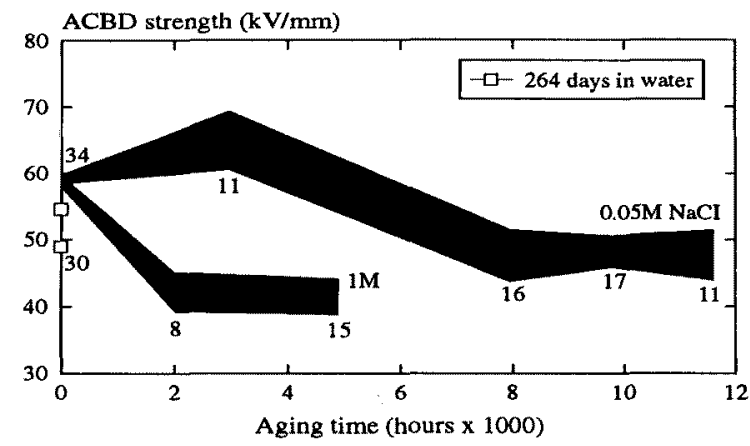

Fig. 7 - ACBD strength (Weibull $90 \%$ confidence intervals) of $\mathrm{HQ4}$ samples as a function of aging time for two $\mathrm{NaCl}$ solution concentration. The numbers refers to the number of sample tested.
On the other hand, the ACBD strength of samples HQ4 is, with the $0.05 \mathrm{M}$ solution, not much affected up to approximately 3000 hours of aging, and is even greater than in the case of samples just immersed in distilled water, afterwards it decreases and stabilizes between 8000 and 12000 hours of aging, also it is quite influenced by the ion concentration. A comparison between Figures 2 and 6, and 3 . and 7 tells us that as aging time increases, water tree length increases also and ACBD strength is lowered, Figure 8 depicts this parallel.

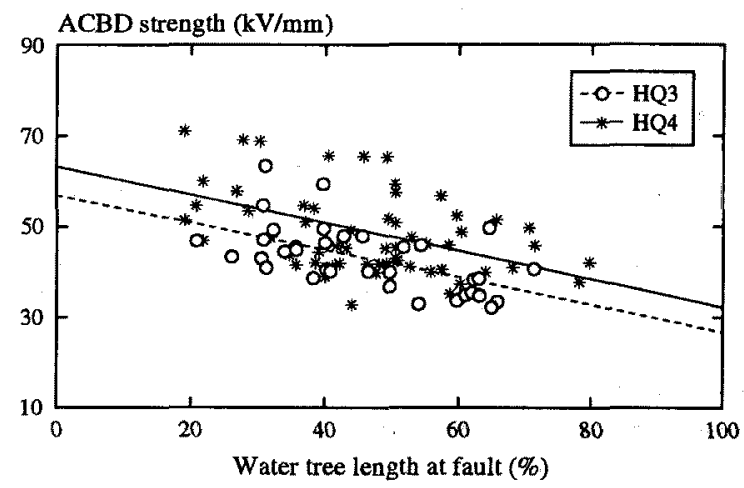

Fig. 8. ACBD strength as a function of water tree length at fault expressed in percent of sample thickness.

An extrapolation of the results shown in Figure 8 gives at $100 \%$ water tree length an ACBD strength of roughly 30 $\mathrm{kV} / \mathrm{mm}$ for both types of samples. This great value and the previous results lead us back to the question of whether water trees are conductive. Our assumption is that water trees, due to their microporous nature [25] and depending on the liquid they are impregnated with, can be dielectric or conductive. In our case, with the solutions that are used, the water trees behave much more as dielectrics. If a higher dielectric constant is assumed $[9,24,26]$ (Koo et al. [24] have measured a permittivity of 6 with respect to air for water trees grown with a $0.05 \mathrm{M} \mathrm{NaCl}$ solution) for water trees compared to untreed XLPE, this will result in an electrical field enhancement at the interface and in the untreed layer; this could explain the reduction in ACBD strength. However, by using the model of homogeneous dielectric ellipsoids, Chen et al. [26] have found that with a permittivity of 6 , even an ellipsoid-shaped water tree having a ratio length/width of 50 , would lead to a field enhancement of less than $3 E_{o}$ ( $E_{o}$ being the electrical field without water trees) at its tip. Since the reduction of the ACBD strength is not systematic and considering the fact that samples having water trees bridging the insulation (Figure 5.b) are capable of sustaining the aging voltage, the electrical field enhancement may thus not be enough. Furthermore, the microscopic examination, at 
magnification of up to 250, of the samples after ACBD tests did not show a single electrical tree grown at the tip, within or even nearby the laboratory-grown water trees. Also most of the ACBD faults did not occur at the maximum laboratorygrown water tree length, only less than $5 \%$ of the tested samples did, as revealed by Figure 9 (if the ACBD faults had occurred at the maximum water tree lengths, all data points would be located on the straight line). Hence we must, conclude that aging samples with the present conditions leads to the growth of non-conductive water trees that have only weak electrical field enhancement at their tip, and consequently no possibility to generate pre-breakdowns or electrical trees. Another way to account for the fact that breakdown did not occur at the maximum water tree length is that the influence of defects near water trees may be predominant. As proposed by Filippini et al. [9] and Chen et al. [26], a defect unable to induce an electrical tree in the absence of water tree may be submitted to an electrical field high enough to induce an electrical tree if a water tree grows in its vicinity. The only electrical trees found with our samples were connected to the breakdown path like branches as shown in Figure 10, but they are much more a consequence of the breakdown fault than a cause.
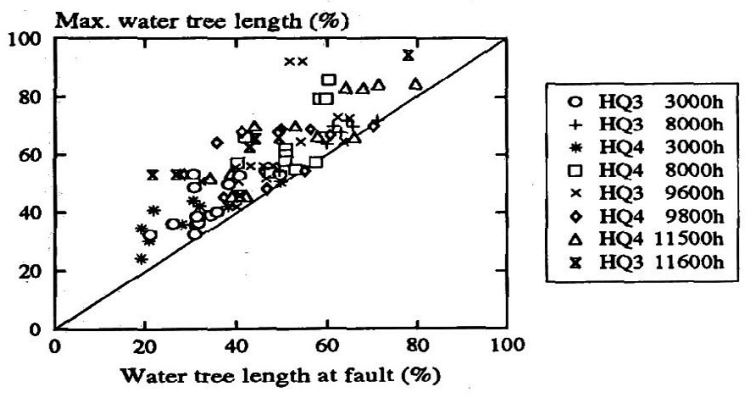

Fig. 9. Maximum water tree length as a function of water tree length at fault, after ACBD tests for several aging times. Both length are expressed in percent of sample thickness.

In order to induce electrical tree inception some HQ3 and HQ4 samples were pitted before aging (see Experimental). The results, shown in Table 2 and Figure 11, indicate that the water tree length and the ACBD strength are greater in the pitted samples in comparison with the non-pitted ones. However, the difference in water tree length between these two types of samples is not so important, less than $25 \%$, taking into consideration the great electric field at the tip of the water needles during aging. For the planar electrode system with a needle in the form of an ellipsoid of revolution, as shown in Figure 12, the electostatic field at the tip $\left(E_{\max }\right)$ of the protrusion is

$$
E_{\max }=\frac{2 V a}{I l\left[\frac{1}{2} \ln \left(\frac{4 a}{r}\right)-1\right]},
$$

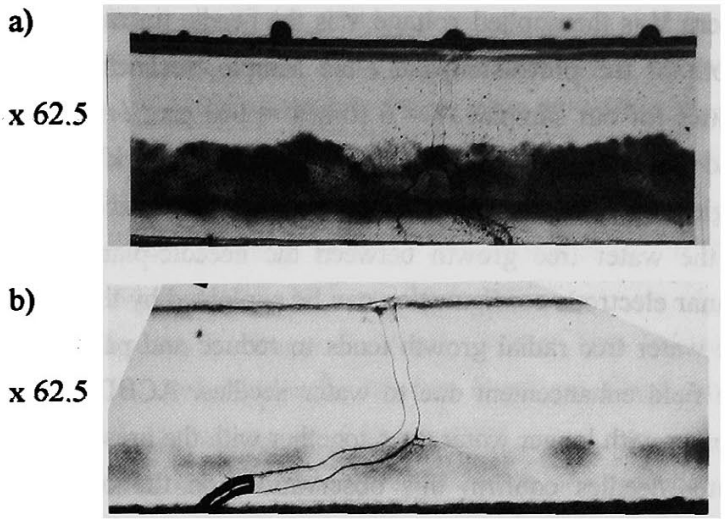

Fig. 10. Breakdown fault showing electrical tree branches:

a) HQ4; $0.05 \mathrm{M} \mathrm{NaCl} ; 7975$ hours; $\mathrm{l}_{\max }=63 \%$; $\mathrm{l}_{\text {fault }}=50 \%$

b) HQ3; $1 \mathrm{M} \mathrm{NaCl} ; 2109$ hours; 1 max $=45 \%$; $1_{\text {fault }}=35 \%$

$1_{\text {max }}$ : maximum lab-water-tree length; $1_{\text {fault }}$ : length at fault

Table 2. Comparison between ordinary and pitted samples aged with $1 \mathrm{M} \mathrm{NaCl}$ solution.

\begin{tabular}{|c|c|c|c|c|}
\hline Sample \# & $\begin{array}{c}\text { Aging time } \\
\text { (hours) }\end{array}$ & $\begin{array}{c}\text { Number of } \\
\text { samples }\end{array}$ & $\begin{array}{c}\text { Max. water tree } \\
\text { length (\%)* }\end{array}$ & $\begin{array}{c}\text { ACBD strength } \\
(\mathrm{kV} / \mathrm{mm})^{* *}\end{array}$ \\
\hline HQ3-pitted & 2237 & 10 & $43-57$ & $41.7-44.8$ \\
\hline HQ3 & 2109 & 5 & $38-45$ & $39.6-42.8$ \\
\hline HQ4-pitted & 2240 & 10 & $43-68$ & $43.3-47.4$ \\
\hline HQ4 & 2040 & 8 & $44-48$ & $39.5-45.2$ \\
\hline
\end{tabular}

* expressed in percent of sample thickness

** Weibull $90 \%$ confidence bounds

a)

$\times 62.5$

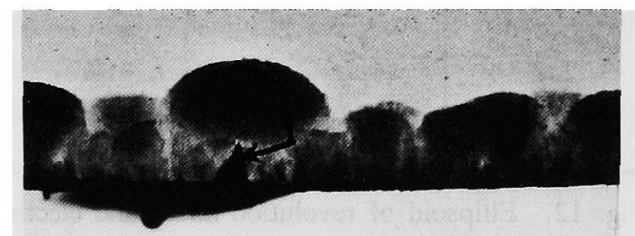

b)

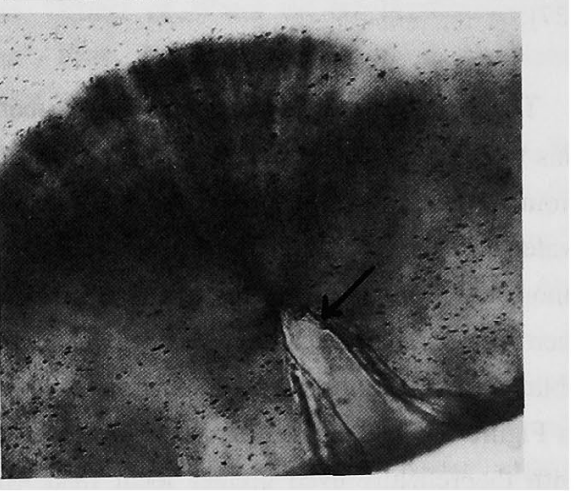

Fig. 11. Examples of pitted samples showing water needles (arrows):

a) $\mathrm{HQ}_{4} ; 1 \mathrm{M} \mathrm{NaCl} ; 2318$ hours; $1_{\max }=56 \%$

b) $\mathrm{HQ} 3 ; 1 \mathrm{M} \mathrm{NaCl}$; 2318 hours; 1 max $=55 \%$

$\mathrm{l}_{\text {max }}$ : maximum lab-water-tree length 
where $\mathrm{V}$ is the applied voltage, $\mathrm{r}$ is the needle tip radius, a the depth of the protrusion and $/$ the sample thickness. Typical values for our samples $(\mathrm{r}=6 \mu \mathrm{m} ; \mathrm{a}=140 \mu \mathrm{m} ; \ell=620 \mu \mathrm{m})$ lead to a maximum electric field of roughly $400 \mathrm{kV} / \mathrm{mm} \mathrm{rms}$ neglecting space charge effects. The small difference observed in the water tree growth between the neeedle-plane and the planar electrode configuration can be explained by the fact that the water tree radial growth tends to reduce and partly cancel the field enhancement due to water needles. ACBD strengths greater with longer water trees together with the presence of the water needles confirm this observation; on the other hand, breakdown faults did not systematically occur at the water needle sites where the lab-water-tree length is, in most of the cases, maximum. In fact, this type of sample did not lead to electrical tree formation due, as in the previous samples, to insufficient electric field enhancement at the tip or in the water trees. Rasikawan et al. [28] and Shimizu et al. [29] have also observed that the electrical tree inception voltage is greater in presence of water trees than without water trees in a needleplane electrode configuration.

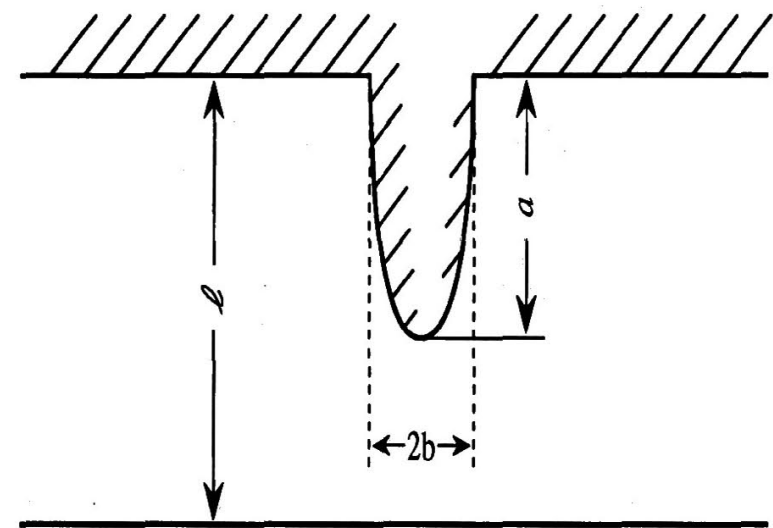

Fig. 12. Ellipsoid of revolution and plane electrode system [27].

The types of samples and/or the aging conditions used in this work do not seem to be suitable to generate electrical trees from water trees. Increasing the electric field by inserting the water needles deeper may have led to electrical tree inception (more likely breakdown) but before water tree growth, since their presence reduces the local field. The same result is obtained with samples containing needle-shape water trees as in Figure $5 \mathrm{c}$ and d, even closer to the opposite electrode, i.e with theoretically even greater local field. Since in service, there is no doubt that a water tree can lead to the formation of an electrical tree, as shown in an example of cable HQ4 by Figure 13, other mechanisms such as surge or lightning impulses or partial discharges at operating voltage may lead to this conversion.
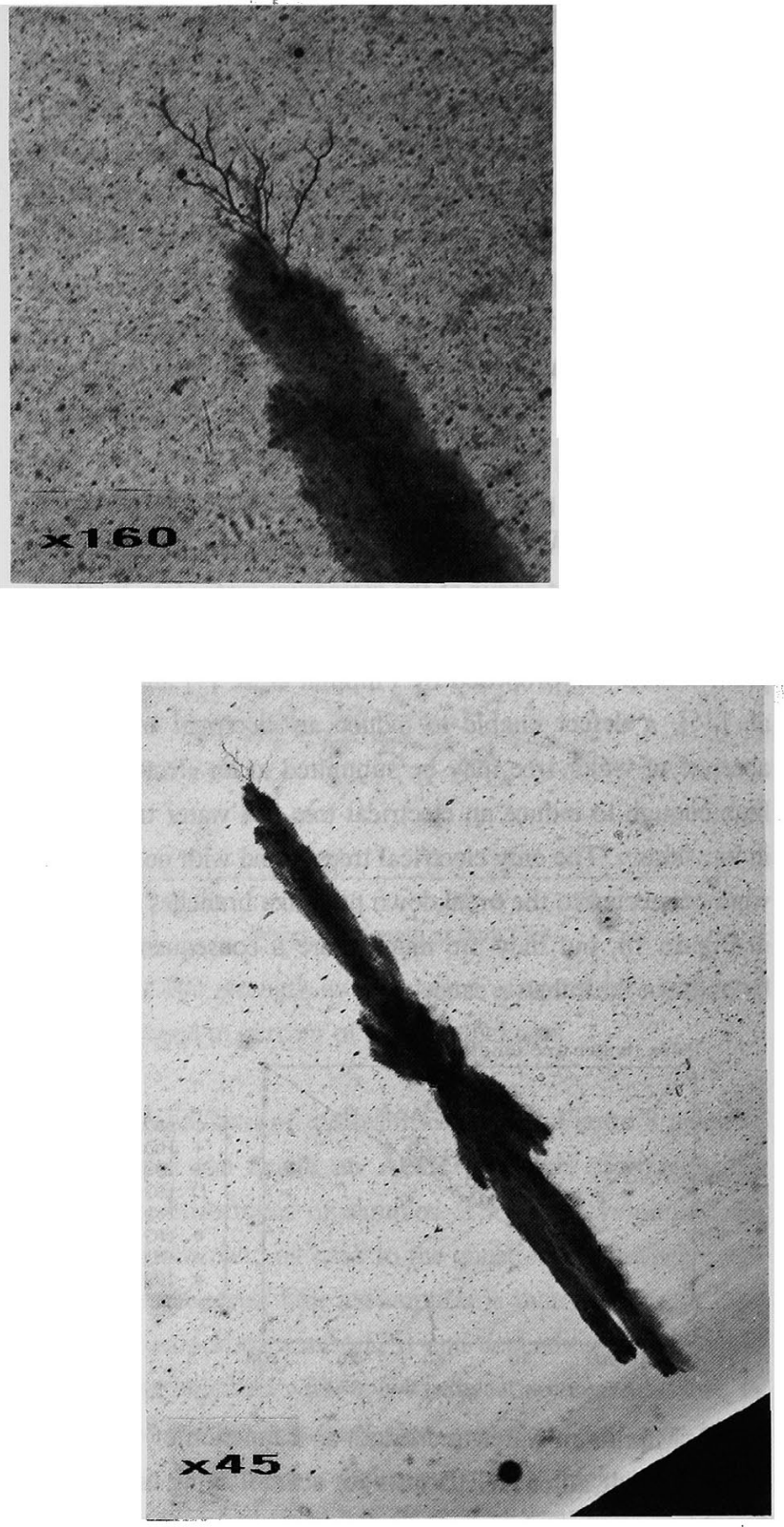

Fig. 13. Example of an electrical tree generated in service conditions from a water tree (a $2 \mathrm{~mm}$ bow-tie tree close to the conductor shield) from cable HQ4.

\section{CONCLUSION}

From this work the following conclusions can be drawn:

* Laboratory water tree growth in thin samples taken from field-aged cables saturated and was was only slightly influenced by $\mathrm{NaCl}$ solution concentration.

* No correlation was found between water tree length and impurity content or microcavity density of the insulation. 
* The length of laboratory-grown water trees was not affected by the presence of water trees developed in service conditions. Water trees grown with the present conditions were not conductive.

* ACBD strength was influenced by water tree length and to a lesser extent by the impurity content of the insulation. Breakdown faults did not occur at the site of the longest water tree.

* No electrical trees were observed after aging or ACBD tests even with pitted samples.

In general, the aging of samples under conditions used in the present work $(0.05$ or I M NaCl solution $10 \mathrm{kV} / \mathrm{mm}$ at $60 \mathrm{~Hz}$ ) and even with water needles, led to the growth of water trees which did not generate pre-breakdowns or electrical trees. Mechanisms other than the electric field enhancement at the tip of the water trees should be considered for the study of the initiation of electrical trees from water trees; parameters such as surge or lightning impulses or partial discharges must therefore be considered.

\section{ACKNOWLEDGMENTS}

The authors would like to thank the Canadian Electrical Association for its financial support and R.J. Densley, A.T. Bulinski and S.S. Bamji from the National Research Council of Canada for providing the first aging cells and for sandblasting the cable ribbons. We are also grateful to G. Sarfi, P.-É. Beaudoin, R. L'Écuyer for their technical assistance .

(Manuscript recived Nov. 14, 1994 ; revised May 15 1995)

\section{REFERENCES}

[1]T. Miyashita, T. Inoue, "Deterioration of Water-Immersed Polyethylene Coated Wire by Treeing and its Accelerated Testing", J. Inst. Electr. Eng. Japan, Vol. 87-10, No. 949, pp. 161-8, 1967.

[2] T. Tabata, T. Fukuda, Z. Iwata, "Investigations of Water Effects on Degradation of Crosslinked Polyethylene Insulated Conductors", Paper 71, TP545-Pwr, IEEE Summer Meeting and Int. Symp. on High Power Testing, pp. 1361-70, 1971.

[3] T.Miyashita, "Deterioration of Water-Immersed Polyethylene-Coated Wire by Treeing", IEEE Trans. Electr. Insul., Vol. EI-6, pp. 129-35, 1971.

[4] J.H. Lawson, "Utility URD Cable Experience", IEEE Electr. Insul. Mag., Vol. 4, N 4 , pp. 16-23, 1988.

[5]W. Kalkner, U. Müller, E. Peschke, H.J. Henkel, R. von Olshausen, "Water Treeing in PE and XLPE Insulated High Voltage Cables", CIGRÉ, paper 21-07, 1982.

[6] J.C. Filippini, J.Y. Koo, Y. Poggi, "Water Treeing and Electrical Treeing", 3rd Int. Conf. on Polym. Insul. Pow.
Cables (Jicâble), pp. 87-92, 1984.

[7] A.T. Bulinski, S.S. Bamji, R.J. Densley, "Factors Affecting the Transition from a Water Tree to an Electrical Tree", Annual Report Conf. IEEE Int. Symp. Electr. Insul., IEEE \#88CH2594-0-DEI, pp. 327-30, 1988.

[8] R.D. Naybour, "Water Treeing - A Personal Saga", IEEE Elec. Insul. Mag., Vol. 6, N5, pp. 20-6, 1990.

[9] J.C. Filippini, Y. Poggi, J. Viard, "Water Tree Induced Breakdown in Polyethylene", 4th Int. Conf. on Cond. and Break. in Sol. Dielectrics, pp. 358-61, 1992.

[10] H. Muto, H. Tanaka, Y. Maruyama, "A Study of Electrical Tree Initiation from Water Tree", Annual Report Conf. Electr. Insul. Diel. Phenom., \#91CH3055-1, pp. 361-6, 1991.

[11] M. Muto, K. Motohashi, Y. Maruyama, Z. Iwata, "Studies on the Initiation and Growth of Electrical Trees", Proc. 4th Int. Conf. on Cond. and Break. in Sol. Dielectr., pp. 461-9, 1992.

[12] S. Pélissou, B. Noirhomme, J.-L. Parpal, "Final Breakdown Mechanism", Proc. 3rd Int. Conf. on Prop. and Appli. of Diel. Mat., pp. 1177-80, 1991.

[13] S. Pélissou, B. Noirhomme, "Final Breakdown in FieldAged XLPE", Proc. 4th Int. Conf. on Conduc. and Break. in Solid Diel., pp. 353-7, 1992.

[14] S. Pélissou, N. Amyot, "Water Trees Conversion in Field-Aged XLPE", Annual Report Conf. Electr. Insul. Diel. Phenom., IEEE \#93CH3269-8, pp. 718-25, 1993.

[15] S. Pélissou, J.-P. Críne, J. Castonguay, S. Haridoss, T.K. Bose, M. Merabet, R. Tobazéon, "Nature et Distribution de l'Eau dans les Câbles Réticulés à la Vapeur", 3rd Int. Conf. on Polym. Insul. Pow. Cables (Jicâble), pp. 270-5, 1987.

[16] S. Pélissou, "Impurities in XLPE Cables", Conf. IEEE Int. Symp. Elec. Insul., IEEE \#90-CH2727-6, pp. 339-42, 1990.

[17] S. Pélissou, "Effect of Water on the Performance of XLPE Insulation", Proc. 3rd Int. Conf. Cond. Break. Solid Diclec., IEEE \#89CH2726-8, pp. 432-6, 1989.

[18] A.T. Bulinski, S.S. Bamji, R.J. Densley, J.-P. Crine, B. Noirhomme, B.S. Bernstein, "Water Treeing in Thermally Preoxidized Cross-linked Polyethylene Cable Insulation", Conf. IEEE Int. Symp. Elec. Insul., IEEE \#90-CH2727-6, pp. 173-77, 1990.

[19] J.Y. Koo, J.C. Filippini, "Effect of physico-chemical factors on the propagation of water trees in polyethylene", Proc. 1st Int. Conf. Cond. Break. Solid Dielec., IEEE \#83CH1836-6-EI, pp. 255-60 (1983).

[20] J.C. Filippini, C.T. Meyer, M. El Kahel, "Some mechanical aspects of the propagation of water trees in polyethylene", Annual Report Conf. Electr. Insul. Diel. Phenom., IEEE \#82CH1773-1, pp. 629-37, 1982. 
[21] J.-P. Crine, S. Pélissou, H. St-Onge, J. St-Pierre, G. Kennedy, A. Houdayer, P. Hinrichsen, "Impuretés Élémentaires et Ioniques dans l'Isolant et les SemiConducteurs de Câbles", 3rd Int. Conf. on Polym. Insul. Pow. Cables (Jicâble), pp. 206-13, 1987.

[22] S. Pélissou, "Relation Between the Halo and Water Trees in XLPE Cables", Annual Report Conf. Electr. Insul. Diel. Phenom., IEEE \#88CH2668-2, pp. 101-8, 1988.

[23] J.Y. Koo, "Internal Structure and Electrical Behavior of Water Trees in Polyethylene", Chongi Hakhoe Nonmunchi, Vol. 35, $\mathrm{N}^{\circ} 12$, pp. 555-9, 1986. (english)

[24] J.Y. Koo, J.D. Cross, M. El-Kahel, C.T. Meyer, J.C. Filippini, "Electrical Behavior and Structure of Water Trees in Relation to their Propagation", Annual Report Conf. Electr. Insul. Diel. Phenom., IEEE \#83CH1902-6, pp. 301-6, 1983.

[25] L.J. Rose, V. Rose, J.J. De Bellet, "Microscopic Failure in Water-Treeing and Fatigue as Revealed by Transmission Electron Microscopy", 3rd Int. Conf. on Polym. Insul. Pow. Cables (Jicâble), pp. 283-9, 1987.

[26] J.L. Chen, J.C. Filippini, "The Morphology and Behavior of the Water Tree", IEEE Trans. Electr. Insul., Vol. 28, pp. 271-286, 1993.

[27] T. Tanaka, A. Greenwood, "Advanced Power Cable Technology", Vol. 1, CRC Press, Inc., Fla., 1983, Chapter 2. [28] S. Rasikawan, H. Ishihara, N. Shimizu, "Comparison Between Water-Treed and Deteriorated Regions", IEEE Tans. on Dielectr. and Electr. Insul., Vol. 1, pp. 597-603, 1994.

[29] N. Shimizu, K. Uchida, S. Rasikawan, "Electrical Tree and Deteriorated Region in Polyethylene", IEEE Trans. on Electr. Insul., Vol. 27, pp. 513-18, 1992.

SERGE PÉLISSOU was born in Castres, France in 1951. He received his B.Sc.A. and M.Sc.A.

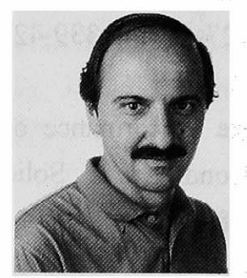
degrees in Engineering physics from the École Polytechnique de Montréal, in 1976 and 1979 respectively.

Since 1977, he has been conducting research at Hydro Quebec's research institute IREQ, on the dielectric properties of polyethylene at high temperatures. He completed his Ph.D. thesis at the institute in 1986. In 1982, he became a permanent member of the scientific staff. His research interests include the dielectric properties of polymers for cables, extruded dielectric cable performance and evaluation, physico-chemical characterization of insulating materials and diagnostic techniques for underground lines. $\mathrm{He}$ is a registered engineer in the province of Québec, a member of IEEE and president of the IEEE-Electrical-Insulation Montréal-Ottawa Chapter.
NORMAND AMYOT was born in Sorengo, Switzerland in 1964. He received his B.Sc.A and M.Sc.A. degrees in Engineering Physics from École Polytechnique de Montréal in 1987 and 1990 respectively.

During his graduate work, he specialized in the structural and electrical characterization of plasma-polymerized polymers. He taught college physics at Collège Jean-de-Brébeuf (Montréal) in 1989-1990 and freshman physics at École Polytechnique de Masuku (Franceville, Gabon) in 1990-91. In 1991, he joined the scientific staff of the Cables and Insulators Department at IREQ, where he is working mainly on electrical properties of insulators. He is a member of IEEE.

BERNARD NOIRHOMME was born in Belgium in 1954.

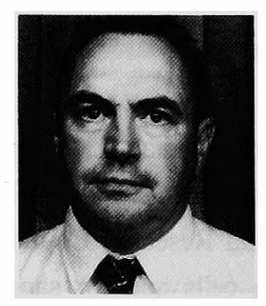
He received his B.Sc. and Ph.D. in chemistry from the Université Libre de Bruxelles in 1976 and 1980 repectively.

Since 1980, he has been conducting research on chemical and dielectric properties of solid insulation. He joined HydroQuébec research institute IREQ in 1987 and was involved in the study of the physico-chemical properties of underground cable insulation. In september 1991, he joined Syprotec Inc. where he held the position of manager of analytical methods and $R \& D$. 